\title{
Zencefilin (Zingiber officinale Roscoe) Diazinon Toksisitesine Karşı Koruyucu Rolünün Allium cepa L. Meristem Hücrelerinde Araştırılması
}

\section{Kültiğin ÇAVUŞOĞLU ${ }^{1}$ (i) Oksal MACAR ${ }^{* 2}$, Tuğçe KALEFETOĞLU MACAR ${ }^{2}$, Emine YALÇIN ${ }^{1}$}

\author{
${ }^{1}$ Giresun University, Faculty of Science and Art, Department of Biology, 28049, Giresun-Turkey \\ ${ }^{2}$ Giresun University, Şebinkarahisar School of Applied Sciences, Department of Food Technology, 28400, \\ Giresun-Turkey
}

Öz: Yaygın olarak kullanılan bir pestisit olan diazinon hedef olmayan canlılar üzerinde toksik etkilere sahiptir. Bu çalışma, diazinonun meristem hücrelerinde teşvik ettiği toksisiteye karşı zencefilin koruyucu ve iyileştirici etkisini fizyolojik, genotoksik ve biyokimyasal parametrelerle araştırmayı hedeflemiştir. Ayrıca kök meristem hücrelerinde meydana gelen hasarlar incelenmiştir. Bu amaçla A. cepa soğanları 6 gruba ayrıldı (kontrol, $240 \mathrm{mg} / \mathrm{L}$ zencefil, $480 \mathrm{mg} / \mathrm{L}$ zencefil, $500 \mathrm{mg} / \mathrm{L}$ diazinon, $500 \mathrm{mg} / \mathrm{L}$ diazinon $+240 \mathrm{mg} / \mathrm{L}$ zencefil ve $500 \mathrm{mg} / \mathrm{L}$ diazinon $+480 \mathrm{mg} / \mathrm{L}$ zencefil). Diazinon süperoksit dismutaz aktivitesi, katalaz aktivitesi, malondialdehit seviyesi, mikronükleus sıklı̆̆ı, kromozomal anormallik yoğunluğu ve meristematik hücre hasarlarını arttırmış; ancak mitotik indeksi, çimlenme yüzdesi, kök uzunluğu, ağırlık artışı azaltmıştır. Zencefil, diazinon ile birlikte uygulandığında doza bağlı olarak tüm bu toksisite göstergelerini düşürmüştür. Bu çalışma, $A$. cepa modeli kullanılarak diazinonun hedef olmayan organizmalar üzerindeki toksik etkilerine karşı zencefilin koruyucu bir rolünü açıkça göstermiş̧ir.

Anahtar kelimeler: antioksidant, fonksiyonel gıda, genotoksisite, mikronükleus

Investigation of the Protective Role of Ginger (Zingiber officinale Roscoe) Against Diazinone Toxicity in Allium cepa L. Meristem Cells

\begin{abstract}
Diazinon, a widely used pesticide, has toxic effects on non-target organisms. This study aimed to investigate the protective and healing effect of ginger against the toxicity promoted by diazinon in meristem cells with physiological, genotoxic and biochemical parameters. In addition, root meristem cell damages were examined. For this purpose, A. cepa bulbs were divided into 6 groups (control, $240 \mathrm{mg} / \mathrm{L}$ ginger, $480 \mathrm{mg} / \mathrm{L}$ ginger, $500 \mathrm{mg} / \mathrm{L}$ diazinone, $500 \mathrm{mg} / \mathrm{L}$ diazinone $+240 \mathrm{mg} / \mathrm{L}$ ginger and $500 \mathrm{mg} / \mathrm{L} \mathrm{diazinone}+480 \mathrm{mg} / \mathrm{L} \mathrm{ginger}$ ). Diazinon increased superoxide dismutase activity, catalase activity, malondialdehyde level, micronucleus frequency, chromosomal abnormality density and meristematic cell damage; but reduced the mitotic index, germination percentage, root length, weight gain. Ginger reduced all these toxicity indicators depending on the dose when administered with diazinon. This study clearly demonstrated the protective role of ginger against the toxic effects of diazinon on non-target organisms using the A. cepa model.
\end{abstract}

Keywords: antioxidant, functional food, genotoxicity, micronucleus

\section{GiRiş}

Günümüzde pestisitlerin tarımsal faaliyetlerde yaygın ve büyük ölçüde kullanılmasından (Saeidi ve ark., 2016) dolayı toprak, gıda ve yüzey-yeraltı su kaynaklarının pestisitlerle kirlenmesi, en önemli çevre sorunlarından biri haline gelmiştir (Dehghani ve ark., 2019). Organofosfatlı bileşikler asetilkolin esteraz enzimini inhibe ederler (Galloway ve Handy, 2003). Son yıllarda dünya çapında en çok kullanılan organofosfatlı insektisitlerden biri olan diazinon (O, O-dietilO- [2-izopropil-6-metil-4-pirimidinil] fosforotioat) insanlar dahil hedef olmayan türlerde çeşitli olumsuz etkilere sebep olmaktadır (Shah ve Iqbal, 2010). Deri, sindirim ve soluma ile vücuda alınan diazinon geri dönüşümsüz kolinesteraz inhibisyonuna sebep olarak hayvan ölümüne yol açabilir (Davies ve Holub, 1980). Orta derecede kalıcı olan diazinonun kalıntıları pek çok tarımsal üründe bulunmakta ve özellikle sucul ve insan ortamlarında bulunan pek çok hedef olmayan canlıyı etkilemektedir (Hajirezaee ve ark., 2016). Sitotoksik, genotoksik ve mutajen özellikleri bilinen diazinon Dünya Sağlık Örgütü (WHO) tarafından, "orta derecede tehlikeli" sınıf II bileşik olarak sınıflandırmıştır (Tabasideh ve ark., 2017).

Zencefil (Zingiber officinale Roscoe), uzun süredir baharat ve bitkisel ilaç olarak yaygın olarak tüketilmektedir (Han ve ark., 2013). Fenolik ve terpen bileşikleri gibi birçok biyoaktif madde içeren zencefil kökü; baş ağrısı, soğuk algınlığı, mide bulantısı ve kusma gibi yaygın hastalıkları tedavi etmek için uzun yıllardır kullanılmaktadır. Başlıcaları zencefiloller, shogaoller ve paradoller (Stoner, 2013) olan pek çok fenolik bileşiğin; zencefile antioksidan, antiinflamatuar, antimikrobiyal ve antikanser kabiliyetler kazandırdığı bilinmektedir (Mao ve ark., 2019).

Allium cepa L. (Soğan), büyük ve az sayıdaki kromozomları ve proliferasyonun hızı nedeniyle mutajenik kimyasalların varlığını göstermede etkili bir test organizmasıdır. Duyarlı olması ve memeli test sistemleri ile iyi korelasyon göstermesi $A$. cepa'nın rutin olarak kullanılmasının diğer

*Sorumlu Yazar: oksal.macar@giresun.edu.tr

Geliş Tarihi: 22 Ekim 2020

Kabul Tarihi: 16 Subat 2021 
sebepleridir (Khanna ve Sharma, 2013). A cepa pestisitler için hedef dışı bir organizma olmasının yanı sıra, çevresel toksisite çalışmaları için, Birleşmiş Milletler Uluslararası Kimyasal Güvenlik Programı (WHO,1985) ve Amerika Birleşik Devletleri Çevre Koruma Ajansı tarafından tanınan bir biyoindikatördür (USEPA, 1996). Genotoksik aktiviteye sahip kimyasalların DNA sentezi ve hücre döngüsü üzerindeki etkileri akış sitometrisi ve $A$. cepa'daki kromozomal aberasyon testi ile tespit edilebilir (Fioresi ve ark., 2020). A. cepa testi mitotik hücrelerdeki tüm kromozomal sapmaları kaydetmek için kullanılan basit ve güvenilir bir tahlildir. Test, hem sitotoksisiteyi hem de genotoksisiteyi ölçmek için kullanılabilir; kök büyüme hızı mitotik indeks ile ilişkilendirilebilir (Pandir, 2018).

Bu çalışmada, diazinonun sebep olduğu toksik etkiler ve zencefilin bu toksisiteye karşı koruyucu rolü $A$. cepa kullanılarak fizyolojik, sitogenetik, biyokimyasal ve anatomik parametrelerle değerlendirilmiştir. Fizyolojik etkilerin değerlendirilmesi için, $A$. cepa soğanlarının çimlenme yüzdesi, kök uzaması ve ağırlık kazanımı belirlenmiştir. Buna ek olarak, diazinon ve zencefilin kök uçları üzerindeki sitogenetik etkilerini araştırmak için mitotik indeks (Mi), mikronükleus (MN) ve kromozomal anormalliklerden (KA) incelenmiştir. A. cepa soğanlarındaki oksidatif stresi taramak için malondialdehit (MDA) seviyeleri ile süperoksit dismutaz (SOD) ve katalaz (KAT) enzimlerinin aktiviteleri kullanılmıştır. Ayrıca diazinon uygulanan $A$. cepa köklerindeki meristematik bütünlük kök ucu kesitlerinin mikroskobik incelenmesi ile değerlendirilmiştir.

\section{MATERYAL VE YÖNTEM}

Çalışmada Giresun'dan ticari olarak satın alınan A. cepa soğanları kullanılmıştır. Tür teşhisi Giresun Üniversitesi, Fen-Edebiyat Fakültesi, Biyoloji Bölümü'nde Dr. Zafer Türkmen tarafından yapılmıştır. Laboratuvara getirilerek renkli dış yapraklarından ve kök kalıntılarından temizlenen soğanlar hassas terazi kullanılarak tartılmıştır. 8.25-8.30 g büyüklükte olan soğanlardan altı grup $(n=50)$ oluşturulmuştur. Birinci grup kontrol grubu olarak kabul edilmiş ve deney boyunca çeşme suyuna maruz bırakılmıştır. Sonraki beş grup sırasıyla $240 \mathrm{mg} / \mathrm{L}$ zencefil, $480 \mathrm{mg} / \mathrm{L}$ zencefil, $500 \mathrm{mg} / \mathrm{L}$ diazinon, $500 \mathrm{mg} / \mathrm{L}$ diazinon + $240 \mathrm{mg} / \mathrm{L}$ zencefil ve $500 \mathrm{mg} / \mathrm{L}$ diazinon $+480 \mathrm{mg} / \mathrm{L}$ zencefil çözeltileri ile muamele edilmiştir (Çizelge 1). Soğanlar steril cam tüplere tabla gövdeleri çözeltiye değecek şekilde yerleştirilmiş ve 72 saatlik deneme süresi boyunca azalan tüplerdeki çözelti miktarları sabit tutulmuştur. Uygulamalar oda sıcaklığında ve karanlık koşullarda gerçekleştirilmiştir. Diazinon ve zencefil çözeltilerinin hazırlanması için ticari olarak edinilen stoklar kullanılmıştır. Diazinon dozunun belirlenmesinde Bıçakçı ve ark. (2017)'ın çalışması dikkate alınmıștır.
Çizelge 1. Deney düzeneği için hazırlanan gruplar ve çözeltiler

\begin{tabular}{ll}
\hline Gruplar & Uygulamalar \\
\hline Grup I (Kontrol) & Çeşme suyu \\
Grup II & $240 \mathrm{mg} / \mathrm{L}$ zencefil \\
Grup III & $480 \mathrm{mg} / \mathrm{L}$ zencefil \\
Grup IV & $500 \mathrm{mg} / \mathrm{L}$ diazinon \\
Grup V & $500 \mathrm{mg} / \mathrm{L}$ diazinon $+240 \mathrm{mg} / \mathrm{L}$ zencefil \\
Grup VI & $500 \mathrm{mg} / \mathrm{L}$ diazinon $+480 \mathrm{mg} / \mathrm{L}$ zencefil \\
\hline
\end{tabular}

Diazinonun ve zencefilin bir arada ve tek tek uygulandıklarında fizyolojik parametrelere etkisini belirlemek için çimlenme yüzdesi (\%), kök uzaması $(\mathrm{cm})$ ve toplam ağırlık artışı (g) incelenmiştir. Çimlenme yüzdesi için her grupta 50, ağırlık artışı için ise her grupta 10 soğan dikkate alınmıştır. Tabla gövdesinden ek kökler beliren soğanlar "çimlenmiş" olarak kabul edilmiştir. Çimlenme yüzdesinin belirlenmesinde Atik ve ark. (2007)'ın yöntemi kullanılmıştır (Eşitlik 1).

Çimlenme Yüzdesi $(\%)=$ (Çimlenmiş soğanların Sayısı / Toplam Soğan Sayısı) $\times 100$ (Eşitlik 1).

Deneme süresinin bitiminde soğanlar yeniden tartılmış ve toplam ağırlık artışının belirlenmesi için soğanların bu son ağırlığı ile ilk ağırlığı arasındaki fark hesaplanmıştır. Grupların ortalama kök uzunluğunu araştırmak üzere her gruptan rastgele seçilen 10 adet soğandan toplamda 100 adet kökün uzunluğu bir cetvel ile ölçülmüştür.

Diazinonun ve zencefilin soğan meristematik hücrelerindeki genotoksik etkilerini araştırmak amacıyla hücrelerdeki Mi, $M N$ ve KA sıklıkları analiz edilmiştir. Analizler için soğanların kök ucundan kesilen $1 \mathrm{~cm}$ uzunluğundaki parçalar kullanılmıştır. Kökler fiksasyon işlemi için 120 dakika boyunca Clarke çözeltisi (3:1 / glasiyel asetik asit:etil alkol) içinde bekletilmiştir. Fiksasyonun ardından \%96'lık etil alkol ile muamele edilen kök numuneleri distile su altında yıkandıktan sonra \%70'lik etil alkole alınarak buzdolabında saklanmıştır. Slaytları hazırlanacak olan kökler $1 \mathrm{~N} \mathrm{HCl}$ çözeltisine alınarak su banyosunda $\left(60{ }^{\circ} \mathrm{C}\right) 14$ dakika tutulmuştur. Bu hidroliz işlemini takiben köklerin $1 \mathrm{~cm}$ 'lik uç kısımları aseto-karmin (\%1) boyası içerisinde 1 gün bekletilerek boyanmıştır. Kök uçlarından alınan $2 \mathrm{~mm}$ 'lik parçalar lama alınmış ve üzerlerine damlatılan \%45'lik asetik asit altında ezilmiştir. Slaytlar binoküler ışık mikroskobunda X500 büyütme altında incelenmiştir (Staykova ve ark., 2005).

$\mathrm{KA}$ ve $\mathrm{MN}$; her grup için ayrı ayrı hazırlanan 10 slayttan 1000 hücrenin, Mi ise her grup için ayrı ayrı hazırlanan 10 slayttan 10000 hücrenin dikkate alınması ile analiz edilmiştir. Bir grup içinde irdelenen 10000 hücre içinden mitoz bölünme gösteren hücreler o grubun $\mathrm{Mi}$ değerini vermiştir. MN olarak değerlendirilen nükleus içi yapıların karakterizasyonunda Fenech ve ark. (2003)'ın kuralları geçerli sayılmıştır. 
A. cepa kök meristematik hücrelerinde diazinon ve zencefil uygulamalarına karşı uyarılan oksidatif stresin ve antioksidan cevabın belirlenmesi için SOD ve KAT enzimlerinin toplam aktiviteleri ölçülmüş ve membran hasarının tespiti için ise MDA miktarı analiz edilmiştir. Analizler tüm gruplarda 3 defa tekrarlanmıştır.

SOD ve KAT aktivitelerinin tayini için gerekli ekstraksiyon Zou ve ark. (2012)'ın yöntemine göre yapılmıştır. Deney süresinin bitiminde kök materyalleri kesilmiş ve distile su ile iyice yıkanmıştır. 0.5 g'lık kök, bir havan yardımı ile doku üzerine sıvı azot eklenerek ezilmiştir. Homojenizasyon işlemi toz haline getirilmiş olan köklerin $5 \mathrm{ml}, 50 \mathrm{mM}$ konsantrasyonda ve $7.8 \mathrm{pH}^{\prime}$ da hazırlanmış olan sodyum fosfat tamponuna alınması ile tamamlanmıştır. Homojenatlar hızlıca santrifüje alınmıştır. $+4{ }^{\circ} C^{\prime}$ de, 20 dakika süresince 14000 rpm'de gerçekleştirilen santrifüj işleminden sonra enzim ekstraktlarını içeren süpernatan kısmı ayrı tüplere alınmıştır. Toplam SOD [EC 1.15.1.1] aktivitesi Beauchamp ve Fridovich (1971)'in; toplam KAT [EC 1.11.1.6] aktivitesi ise Beers ve Sizer (1952)'in yöntemine göre belirlenmiştir. Toplam SOD aktivitesi için $0.01 \mathrm{ml}$ enzim ekstraktı; toplam KAT aktivitesini belirlemek için ise $0.2 \mathrm{ml}$ enzim ekstraktı kullanılmıştır. Enzim ekstraktının eklendiği reaksiyon ortamı SOD enzimi için 7.8 pH'taki 0.05 M'lık 1.5 $\mathrm{ml}$ sodyum fosfat tamponu, $0.3 \mathrm{ml} 130 \mathrm{mM}$ 'lık metionin, 0.3 $\mathrm{ml} 20 \mu \mathrm{M}^{\prime}$ lık riboflavin, $0.3 \mathrm{ml} 0.1$ mM'lık EDTA-Na, $0.3 \mathrm{ml}$ $750 \mu \mathrm{M}^{\prime}$ 'ık nitroblue tetrazolium klorür, $0.01 \mathrm{ml} \% 4^{\prime} l u ̈ k$ polivinilpirolidon ve $0.28 \mathrm{ml}$ distile su içermektedir. Reaksiyon karışımını içeren spektrofotometre küveti 375 $\mu \mathrm{mol} \mathrm{m} \mathrm{m}^{-2} \mathrm{~s}^{-1}$ floresan ışığın karşısında 15 dakika bekletilerek tepkimenin gerçekleşmesi sağlanmıştır. Bu sürenin sonunda örneklerin absorbansı $560 \mathrm{~nm}$ 'de spektrofotometrik olarak okunmuştur. Toplam SOD aktivitesi ünite $\mathrm{mg}^{-1}$ taze ağırlık (U mg ${ }^{-1} \mathrm{FW}$ ) olarak verilmiştir. KAT aktivitesinin ölçümü için enzim ekstraktı $7.8 \mathrm{pH}$ 'taki $0.2 \mathrm{M}^{\prime}$ lık $1.5 \mathrm{ml}$ sodyum fosfat tamponu, $0.3 \mathrm{ml} 0.1 \mathrm{M}^{\prime}$ lık hidrojen peroksit ve distile su içeren tepkime ortamına eklenmiştir. Ekstraktın eklenmesi ile hidrojen peroksitin enzimatik olarak azaltıması 240 $\mathrm{nm}$ 'de spektrofotometrik olarak takip edilmiştir. KAT aktivitesi OD240 $\mathrm{nm} \mathrm{min} \mathrm{g}^{-1}$ taze ağırlık $\left(\mathrm{OD}_{240 \mathrm{~nm}} \mathrm{~min} \mathrm{~g}^{-1}\right.$ FW) olarak verilmiştir.
ÇAVUŞOĞLU K, MACAR O, KALEFETOĞLU MACAR T, YALÇIN E Diazinon ve zencefilin hücre zarlarının bütünlüğü üzerindeki etkilerini incelemek için MDA tayini yapılmıştır. $0.5 \mathrm{~g}$ kök kök materyali \%5'lik trikloroasetik asit (TCA) içinde havanda ezilmiştir. Oda sıcaklığında gerçekleşen homojenizasyon işleminden sonra homojenat yine oda sıcaklığında 12000 rpm'de 15 dakika santrifüjlenmiştir. Süpernatan kendisi ile eşit hacimde \%20'lik TCA ve \%0.5'lik tiobarbütirik asit (TBA) karışıma eklenmiştir. Yeni karışım su banyosunda 30 dakika $+96{ }^{\circ} \mathrm{C}^{\prime}$ de tutularak tepkimenin gerçekleşmesi sağlanmıştır. Süre bitiminde reaksiyonun sonlandırılması için tüpler buz banyosuna taşınmıştır. Oda sıcaklığında 10000 rpm'de 5 dakika santrifüjlenen örneklerden süpernatan kısımları ayrılmıştır. Süpernatanın absorbansı $532 \mathrm{~nm}$ dalga boyunda spektrofotometrik olarak okunmuş ve $\mu \mathrm{M} \mathrm{g}^{-1}$ taze ağırlık $\left(\mu \mathrm{M} \mathrm{g}^{-1} \mathrm{FW}\right.$ ) olarak hesaplanmıştır (Ekstinksiyon katsayısı; $155 \mathrm{M}^{-1} \mathrm{~cm}^{-1}$ ) (Unyayar ve ark., 2006).

Diazinon ve zencefilin meristematik bütünlüğe etkisini incelemek için kökler deney süresinin bitiminde hasat edilerek distile su ile iyice yıkanmıştır. Keskin bir jilet ile kökün meristem kısmından enine kesit alınmıştır. Kesitler bir lam üzerine alınarak bir damla \%5'lik metilen mavisi ile boyanmıştır. Slaytlar binoküler ışık mikroskobunda X500 büyütmede incelenmiştir. Çalışma veriler ortalama $\pm S D$ olarak gösterilmiştir, Ortalama verileri arasındaki istatistiksel farklar $(p<0.05)$ SPSS 23.0 programında one-way ANOVA ve Duncan testleri ile değerlendirilmiştir.

\section{BULGULAR VE TARTIŞMA}

Diazinon ve zencefil uygulamasının çimlenme yüzdesi (\%) kök uzunluğu (cm), ve ağırlık kazanımı (g) üzerindeki etkileri Çizelge 2'de gösterilmiştir. Zencefil uygulanan Grup II ve Grup III ile kontrol grubu ile karşılaştırıldığında çimlenme yüzdesi, kök uzunluğu ve ağırlık kazanımında istatistiksel olarak önemli bir fark bulunmamıştır ( $p>0.05$ ). Zencefil uygulaması $A$. cepa köklerinin büyüme fizyolojisinde olumsuz bir etkiye neden olmamıştır. Elde edilen bu sonuca benzer bir şekilde literatürde zencefilin bitki veya hayvan fizyolojisinde negatif bir etkisine rastlanılmamıştır. Öte yandan diazinon uygulanan Grup IV'ün çimlenme yüzdesi

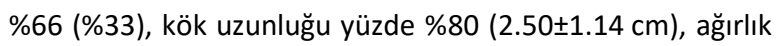
kazanımı ise yüzde \%89 (1.50 g) azalmıştır ( $p<0.05)$. Diazinon uygulaması $A$. cepa soğanlarının çimlenmesi ve

Çizelge 2. Diazinon ve zencefil uygulamasının seçilen fizyolojik parametreler üzerine etkisi

\begin{tabular}{lccc}
\hline Gruplar & Çimlenme yüzdesi $(\%)(\mathbf{n = 5 0})$ & Kök uzunluğu $(\mathbf{c m})(\mathbf{n = 1 0})$ & Ağırlık azanımı $(\mathbf{g})(\mathbf{n}=\mathbf{1 0})$ \\
\hline Grup I & 99 & $12.50 \pm 3.60^{\mathrm{a}}$ & $+13.00^{\mathrm{a}}$ \\
Grup II & 98 & $12.80 \pm 3.76^{\mathrm{a}}$ & $+13.50^{\mathrm{a}}$ \\
Grup III & 100 & $13.10 \pm 3.94^{\mathrm{a}}$ & $+13.94^{\mathrm{a}}$ \\
Grup IV & 33 & $2.50 \pm 1.14^{\mathrm{d}}$ & $+1.50^{\mathrm{d}}$ \\
Grup V & 45 & $4.60 \pm 1.45^{\mathrm{c}}$ & $+4.00^{\mathrm{c}}$ \\
Grup VI & 60 & $7.20 \pm 1.96^{\mathrm{b}}$ & $+6.84^{\mathrm{b}}$ \\
\hline
\end{tabular}

*Grup I: Kontrol, Grup II: 240 mg/L zencefil, Grup III: 480 mg/L zencefil, Grup IV: 500 mg/L diazinon, Grup V: 500 mg/L diazinon + 240 mg/L zencefil, Grup VI: $500 \mathrm{mg} / \mathrm{L}$ diazinon $+480 \mathrm{mg} / \mathrm{L}$ zencefil. Aynı sütün içerisinde farklı harfler ${ }^{(\mathrm{a}-\mathrm{d})}$ ile gösterilen ortalamalar $\mathrm{p}<0.05^{\prime}$ de önemlidir. 
gelişmesini olumsuz yönde etkilemiştir. Bıçakçı ve ark. (2017) diazinon uygulamasının doza bağlı olarak bu üç parametreyi olumsuz etkilediğini belirtmiştir. Ek olarak Grup IV ile karşılaştırıldıklarında, dizazinona ile birlikte zencefil verilen Grup V ve Grup VI'nın çimlenme yüzdesi, kök uzunluğu ve ağılık kazanımında istatistiksel olarak önemli bir iyileşme görülmüştür $(p<0.05)$. Çimlenme yüzdesi (\%60), kök uzunluğu $(7.20 \pm 1.96 \mathrm{~cm})$ ve ağırlık kazanımındaki $(6.84 \mathrm{~g})$ en fazla iyileşme Grup VI'da belirlenmiştir $(p<0.05)$. Zencefilin dianizonun etkilerini azalmasına dair daha önce yapılmış bir çalışma bulunmamıştır. Abdelkhalek ve ark. (2017) Spirulina platensis Geitler alginin yüksek antioksidan gücü sayesinde diazinonun nil çiklet balı̆̆ (Oreochromis niloticus L.) üzeinde oluşturduğu oksidatif hasara karşı iyileştirici gücü olduğunu belirtmişlerdir. Aynı şekilde çok güçlü bir antioksidan olan (Mao ve ark., 2019) zencefilin, diazinondan kaynaklanan oksidatif baskıyı hafifleterek kök gelişimindeki düşüşü düzelmesi en olası açıklamadır.

Dianizon ve zencefil uygulamalarının MI ve MN frekansları üzerindeki sitogenetik etkisi Çizelge 3 'te sunulmuştur. Zencefil uygulaması, Grup II (862.00 \pm 23.21$)$ ve Grup III'ün $(884.00 \pm 24.55) \mathrm{Ml}$ değerlerinde Grup I ile $(875.00 \pm 24.18)$ göre anlamlı bir farka $(p>0.05)$ neden olmamıştır. Buna karşılık, dianizon uygulaması, Grup IV'ün Mi'sinde $(485.00 \pm 09.16)$ keskin bir düşüşe neden olmuştur $(p<0.05)$. Öte yandan, dianizon ile hazırlanan çözeltiye zencefil eklenen Grup V $(552.00 \pm 10.48)$ ve Grup VI'ün

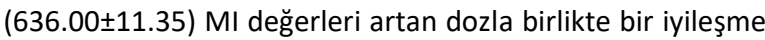
görülmüştür $(p<0.05)$. Tek başına zencefil uygulaması $A$. сера meristem hücrelerin bölünme kapasitesini etkilemezken zencefilin diazinon ile birlikte verilmesi diazinonun oluşturduğu mitotik bölünmedeki yavaşlığı hafifletebilmektedir. MI sonuçlarının hücre bölünme hızının bir göstergesi olduğu göz önüne alındığında, diazinonun uygulamasının MI değerlerini baskılaması kök uzunluğu ve ağırlık artışı gibi büyüme parametrelerindeki geri kalmayı açıklamaktadır. Diazinonun MI üzerindeki olumsuz etkisi daha önce bir genotoksisite unsuru olarak belirtilmiştir (Bıçakçı ve ark., 2017; Pandir, 2018).
Gözlenmesi en kolay genetik hasarlardan biri olan MN oluşumu zencefil ve diazinonun genotoksik etkilerini belirlemek için incelenmiştir. Grup I $(0.24 \pm 0.36)$, Grup II $(0.16 \pm 0.24)$ ve Grup III'ün $(0.10 \pm 0.12) \mathrm{MN}$ frekansları arasında istatistiksel fark bulunmamıştır (Çizelge 3). Ancak, diazinona maruz kalan Grup IV'ün $(50.00 \pm 7.65)$ MN frekansında Grup l'e göre keskin bir şekilde artış gözlenmiştir $(p<0.05)$. Grup V $(40.60 \pm 6.61)$ ve Grup VI (24.70 \pm 4.85$)$ değerleri artan zencefil miktarına paralel olarak kademeli olarak azalmıştır. Bıçakçı ve ark. (2017) ve Pandir (2018) diazinon uygulamasının $A$. cepa'da MN frekansını önemli bir şekilde arttırdığını belirtmişlerdir. Benzer şekilde diazinonun fare ve insan hücrelerinde de MN artışına yol açtığı bilinmektedir (Sh ve ark., 2020; Karamian ve ark., 2016). MN sonuçları diazinonun genotoksik etkiye sahip olduğunu ve zencefilin bu olumsuz etkiyi hafiflettiğini açıkça göstermiştir. Fenech (1993) MN oluşumunun oksidatif stresten kaynaklı DNA kırıklarından kaynaklanabildiğini söylemiştir. Bu bakış açısından yüksek antioksidan gücü sayesinde zencefil $A$. серa meristem hücrelerini diazinon kaynaklı $M N$ ve genotoksisite oluşumuna karşı korumaktadır. Zencefil uygulanan Grup II ve Grup III'te kromozomal anormallik görülmemesi bu sonucu desteklemektedir. Almostady ve ark. (2015) zencefilin herhangi bir genotoksik etkiye sahip olmadığını belirmiştir. Dianizon uygulanan Grup IV'de MN haricinde görülen diğer kromozomal anormallikler çoktan aza göre sırasıyla fragment, yapışkan kromozom, köprü, kromatinin eşit olmayan dağılımı ve vakuollü nükleusdur (Şekil 1). Pandir (2018) diazinonun A. cepa'da yoğun kromozomal anormallikler yaptığını belirtmiştir. Çalışmamıza benzer şekilde Bıçakçı ve ark. (2017) diazinon uygulanan $A$. cepa'nın meristem hücrelerinde fragment, yapışkan kromozom, kromozom köprüsü ve kromatinin eşit olmayan dağıııı dağılımı görüldüğünden bahsetmiştir. Mi'nin tersi bir şekilde diazinon ile birlikte zencefil uygulanan Grup V ve Grup VI'da tüm kromozomal anormallikler doza bağlı bir şekilde azalmıştır $(p<0.05)$. Hem $\mathrm{MN}$ hem de kromozomal anormallikler klastojenitenin öncü belirtilerindendir (Kalefetoğlu Macar ve ark., 2020). Dianizonun sebep olduğu

Çizelge 3. Diazinon uygulamasının teşvik ettiği genotoksisiteye karşı zencefilin koruyucu rolü

\begin{tabular}{lccccccc}
\hline Gruplar & MI & MN & FRG & YK & K & KED & VN \\
\hline Grup I & $875.00 \pm 24.18^{\mathrm{a}}$ & $0.24 \pm 0.36^{\mathrm{d}}$ & $0.00 \pm 0.00^{\mathrm{d}}$ & $0.20 \pm 0.18^{\mathrm{d}}$ & $0.00 \pm 0.00^{\mathrm{d}}$ & $0.20 \pm 0.24^{\mathrm{d}}$ & $00 \pm 0.00^{\mathrm{d}}$ \\
Grup II & $862.00 \pm 23.21^{\mathrm{a}}$ & $0.16 \pm 0.24^{\mathrm{d}}$ & $0.00 \pm 0.00^{\mathrm{d}}$ & $0.10 \pm 0.11^{\mathrm{d}}$ & $0.00 \pm 0.00^{\mathrm{d}}$ & $0.10 \pm 0.14^{\mathrm{d}}$ & $0.00 \pm 0.00^{\mathrm{d}}$ \\
Grup III & $884.00 \pm 24.55^{\mathrm{a}}$ & $0.10 \pm 0.12^{\mathrm{d}}$ & $0.00 \pm 0.00^{\mathrm{d}}$ & $0.00 \pm 0.00^{\mathrm{d}}$ & $0.00 \pm 0.00^{\mathrm{d}}$ & $0.10 \pm 0.12^{\mathrm{d}}$ & $0.00 \pm 0.00^{\mathrm{d}}$ \\
Grup IV & $485.00 \pm 09.16^{\mathrm{d}}$ & $50.00 \pm 7.65^{\mathrm{a}}$ & $58.60 \pm 5.12^{\mathrm{a}}$ & $40.10 \pm 4.63^{\mathrm{a}}$ & $29.30 \pm 3.88^{\mathrm{a}}$ & $22.10 \pm 3.24^{\mathrm{a}}$ & $12.60 \pm 2.10^{\mathrm{a}}$ \\
Grup V & $552.00 \pm 10.48^{\mathrm{c}}$ & $40.60 \pm 6.61^{\mathrm{b}}$ & $48.80 \pm 4.96^{\mathrm{b}}$ & $31.40 \pm 4.22^{\mathrm{b}}$ & $21.60 \pm 3.54^{\mathrm{b}}$ & $11.60 \pm 2.16^{\mathrm{b}}$ & $7.90 \pm 1.38^{\mathrm{b}}$ \\
Grup VI & $636.00 \pm 11.35^{\mathrm{b}}$ & $24.70 \pm 4.85^{\mathrm{c}}$ & $32.50 \pm 4.16^{\mathrm{c}}$ & $22.90 \pm 3.73^{\mathrm{c}}$ & $13.70 \pm 2.42^{\mathrm{c}}$ & $6.30 \pm 1.15^{\mathrm{c}}$ & $2.70 \pm 1.12^{\mathrm{c}}$ \\
\hline
\end{tabular}

*Grup I: Kontrol, Grup II: 240 mg/L zencefil, Grup III: 480 mg/L zencefil, Grup IV: 500 mg/L diazinon, Grup V: 500 mg/L diazinon + 240 mg/L zencefil, Grup VI: $500 \mathrm{mg} / \mathrm{L}$ diazinon $+480 \mathrm{mg} / \mathrm{L}$ zencefil. Aynı sütün içerisinde farklı harfler ${ }^{(\mathrm{a}-\mathrm{d})}$ ile gösterilen ortalamalar p<0.05'de önemlidir. MN: mikronükleus, Mi: mitotik indeks, FRG: fragment, YK: yapışkan kromozom, K: köprü, KED: kromatinin eşit olmayan dağılımı, VN: vakuollü nükleus. 


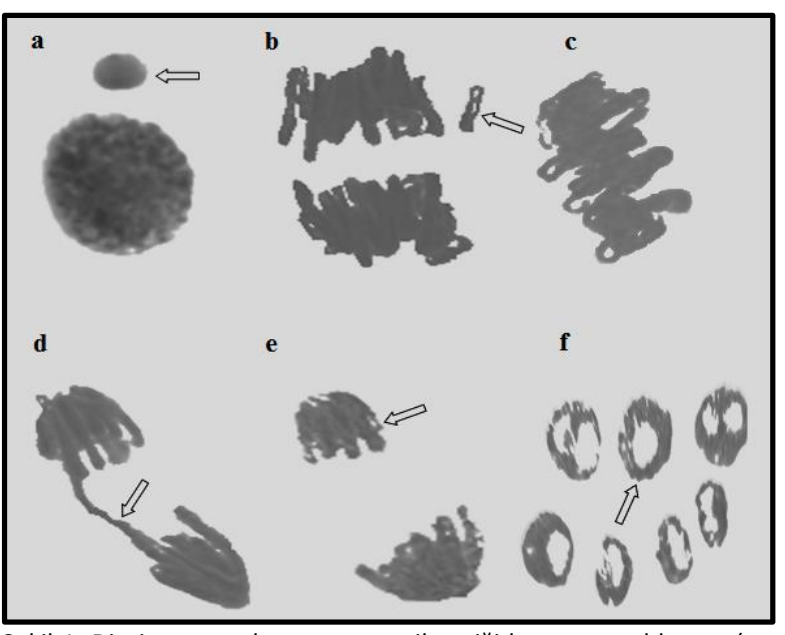

Şekil 1. Diazinon uygulamasının teşvik ettiği kromozomal hasar. (a: $\mathrm{MN}$, b: fragment, c: yapışkan kromozom, d: köprü, e: kromatinin eşit olmayan dağılımı, f: vakuollü nükleus)

genotoksisiteyi hafifleten zencefil, kanser gibi genetik hasardan kaynaklanan hastalıklara karşı etkili bir fonksiyonel gıda olma potansiyeline sahiptir.

Diazinon ve zencefil uygulamalarının biyokimyasal parametreler üzerine etkisi Çizelge $4^{\prime}$ te verilmiştir. Hücrelerdeki oksidatif dengenin korunmasında antioksidan enzimlerin önemi büyüktür (Hao ve Liu, 2019). SOD ve KAT enzimlerinin aktivitesi hücrelerde oluşan serbest radikal kaynaklı oksidatif strese karşı canlıların sahip olduğu en önemli savunma mekanizmalarındandır. SOD enzimi hücrede oluşan süperoksit radikallerinin yüksüz hidrojen peroksit moleküllerine dönüştürülmesinde başrol oynarken; KAT enzimi, enzimatik ya da enzimatik olmayan yollarla oluşan, bu hidrojen peroksit moleküllerinin suya ve oksijene dönüştürülmesinde kilit mekanizmalardan birini oluşturmaktadır. Hücre içinde bu enzimlerin de katkısı ile korunan oksidatif dengenin bozulması halinde yoğunlukları giderek artan serbest radikaller makromoleküllere ve hücre membranlarına ağır hasarlar vermektedir. MDA molekülü oksidatif stresin hem sonucu hem de habercisi olarak oluşan bir madde olup; hücre membranlarında gerçekleşen lipid peroksidasyonunun son ürünüdür (Zulaikhah, 2018). Bu durumda; MDA artışının membran hasarının önemli bir göstergesi olduğu söylenebilir. Mevcut çalışmada tek başına uygulanan zencefil dozlarının (Grup II ve III) kontrol grubu
ÇAVUŞOĞLU K, MACAR O, KALEFETOĞLU MACAR T, YALÇIN E ile kıyaslandığında SOD ve KAT aktiviteleri ile MDA oluşumu bakımından istatistiksel olarak önemli bir fark yaratmadığı açıkça görülmektedir $(p>0.05)$. Bu durum, zencefilin oksidatif strese ya da membranlarda hasara yol açmadığını net biçimde göstermiştir. Bu durumun aksine; Grup IV'te hem SOD ve KAT hem de MDA kontrol grubuna göre oldukça ciddi bir artış sergilemiştir. Grup IV'teki SOD aktivitesi kontrol grubunun yaklaşık olarak 2.8 katı iken; KAT aktivitesi ise kontrolün yaklaşık 2.6 katıdır. Grup IV'ün MDA miktarında görülen kontrolün 3 katı olan artı̧ miktarı; SOD ve KAT aktivitelerinde görülen büyük artışa rağmen diazinon uygulamasının membranlarda önemli hasara yol açtığını açıkça göstermiştir. Çalışmamızla uyumlu bir şekilde; diazinonun ciddi bir şekilde oksidatif strese sebep olduğunu gösteren çalışmalar mevcuttur (Shah ve Iqbal, 2010; ElShenawy ve ark., 2010; Abdel-Daim ve ark.; 2018). Mevcut hayvan denemelerine karşın; bitki hücrelerinde diazinon kaynaklı oksidatif stresin gösterildiği başka bir çalışmaya literatürde rastlanılmamıştır. Çalışmamızda diazinon ile birlikte verilen iki farklı dozdaki zencefil (Grup V ve VI) biyokimyasal parametrelerde doza bağı etki göstermiştir. Diazinon ile birlikte uygulanan $240 \mathrm{mg} / \mathrm{L}$ zencefil, Grup V'teki SOD aktivitesinin sadece diazinon uygulanan Grup IV'e göre \%16 azalma gösterirken; diazinon ile birlikte uygulanan $480 \mathrm{mg} / \mathrm{L}$ zencefil Grup VI'daki SOD aktivitesi sadece diazinon uygulanan Grup IV'e göre $\% 40$ azalmıştır. Öte yandan KAT aktivitesi Grup V'te Grup IV'e göre \%10 azalırken; Grup VI'da Grup IV'e göre \%26 azalma göstermiştir. Bu durum; ortama eklenen ve enzimatik olmayan bir antioksidan olan zencefilin antioksidan savunmaya katkısı sonucu enzim aktivitelerinin hafifleme göstermesi şeklinde yorumlanabilir. Bu durumu doğrular şekilde düşük dozda uygulanan zencefil Grup V'teki MDA aktivitesini Grup IV'e göre \%23, yüksek dozda uygulanan zencefil Grup VI'daki MDA aktivitesini Grup IV'e göre \%47 azaltmıştır. Sadece diazinon uygulaması ile kıyaslandığında; diazinon ile beraber hem düşük hem de yüksek dozda uygulanan zencefil membran hasarını kademeli olarak azaltmıştır. Zencefilin doğrudan oluşan ve diazinon uygulaması gibi dolaylı olarak teşvik edilen oksidatif strese karşı koruyucu etkisi son yıllarda dikkat çekmekte ve çeşitli

Çizelge 4. Diazinon ve zencefil uygulamasının seçilen biyokimyasal parametreler üzerine etkisi

\begin{tabular}{lccc}
\hline Gruplar & MDA $\left(\mu \mathrm{M} \mathrm{g}^{-1} \mathrm{FW}\right)$ & SOD $\left(\mathbf{U ~ m g}^{-1} \mathrm{FW}\right)$ & KAT $_{\left(\mathbf{O D}_{240 \mathrm{~nm}} \mathbf{m i n ~}^{-1} \mathrm{FW}\right)}$ \\
\hline Grup I & $9.20 \pm 1.74^{\mathrm{d}}$ & $75.00 \pm 5.84^{\mathrm{d}}$ & $1.12 \pm 0.21^{\mathrm{d}}$ \\
Grup II & $9.00 \pm 1.68^{\mathrm{d}}$ & $77.60 \pm 5.92^{\mathrm{d}}$ & $1.10 \pm 0.19^{\mathrm{d}}$ \\
Grup III & $9.10 \pm 1.60^{\mathrm{d}}$ & $74.00 \pm 5.36^{\mathrm{d}}$ & $0.98 \pm 0.16^{\mathrm{d}}$ \\
Grup IV & $36.80 \pm 5.12^{\mathrm{a}}$ & $210.60 \pm 9.62^{\mathrm{a}}$ & $2.92 \pm 0.36^{\mathrm{a}}$ \\
Grup V & $28.40 \pm 4.61^{\mathrm{b}}$ & $176.50 \pm 7.15^{\mathrm{b}}$ & $2.61 \pm 0.32^{\mathrm{b}}$ \\
Grup VI & $19.60 \pm 3.77^{\mathrm{c}}$ & $125.00 \pm 6.89^{\mathrm{c}}$ & $2.15 \pm 0.24^{\mathrm{c}}$ \\
\hline
\end{tabular}

*Grup I: Kontrol, Grup II: 240 mg/L zencefil, Grup III: 480 mg/L zencefil, Grup IV: 500 mg/L Diazinon, Grup V: 500 mg/L Diazinon +240 mg/L zencefil, Grup VI: $500 \mathrm{mg} / \mathrm{L}$ Diazinon $+480 \mathrm{mg} / \mathrm{L}$ zencefil. sütün içerisinde farklı harfler ${ }^{(a-d)}$ ile gösterilen ortalamalar $p<0.05$ 'de önemlidir. 
organizmalarda değişik stres kaynaklarına karşı çalışılmaktadır (Al Hroob ve ark., 2018; Zargar ve ark., 2020). Zencefilin eşsiz antioksidan kapasitesi; içeriğinde bulunan 6 -şogaol ve zingeron gibi biyoaktif bileşenlerden ve bu bileşiklerin türevlerinden kaynaklanmakta olup; içerikteki bu polifenoller sayesinde zencefil ile hazırlanan ektraktlar antioksidan, anti-enflamatuar ve antibakteriyel özellikler göstermektedir (Trimedona ve ark., 2020).

Çizelge 5 ve Şekil 2; diazinon ve zencefil uygulamalarının meristematik hücrelerdeki yapısal bütünlüğe etkisini göstermektedir. Sadece zencefil uygulanan gruplardaki meristematik hücrelerde (Grup II ve III) kontrole göre (Grup I) herhangi bir meristematik hasar bulgusuna rastlanmamıştır. Buna karşın; Grup IV'te diazinon uygulaması tarafından teşvik edilen meristematik hasarlar; epidermis hücre hasarı, korteks hücre çeperinde kalınlaşma, korteks hücrelerinde madde birikimi, binüklear hücre, yassılaşmış hücre çekirdeği ve belirgin olmayan iletim doku şeklinde sıralanmıştır. Meristematik hücrelerde görülen hasarlar seviyelerine göre; şiddetli hasarlar (+++), orta şiddetli hasarlar (++), az hasarlar (+) olarak sıralanmıştır. Bu skalaya göre; epidermis hücre hasarı, korteks hücre çeperinde kalınlaşma, yassılaşmış hücre çekirdeği ve belirgin olmayan iletim doku Grup IV'te gözlenen şiddetli hasarlar iken; korteks hücrelerinde madde birikimi ve binuklear hücre Grup IV'te belirlenen orta hasarlardır (Şekil 2). Diazinon ile birlikte zencefil uygulanan Grup V ve Grup VI'daki meristematik hasarlar; verilen zencefil dozuna göre azalma göstermiş ve hatta diazinon ile beraber $480 \mathrm{mg} / \mathrm{L}$

Çizelge 5. Diazinon teşvik ettiği meristematik hücre hasarlarına karşı zencefilin koruyucu rolü

\begin{tabular}{lllllll}
\hline Hasarlar & EHH & KHK & KHMB & BH & YHÇ & BID \\
\hline Grup I & - & - & - & - & - & - \\
Grup II & - & - & - & - & - & - \\
Grup III & - & - & - & + & + & +++ \\
Grup IV & +++ & +++ & ++ & ++ & ++ \\
Grup V & ++ & ++ & + & + & + \\
Grup VI & + & + & - & + & + \\
\hline
\end{tabular}

*Grup I: Kontrol, Grup II: 240 mg/L zencefil, Grup III: 480 mg/L zencefil, Grup IV: 500 mg/L Diazinon, Grup V: 500 mg/L Diazinon + 240 mg/L zencefil, Grup VI: 500 mg/L Diazinon + 480 mg/L zencefil. EHH: epidermis hücre hasarı, KHK: korteks hücre çeperinde kalınlaşma, KHMB: korteks hücrelerinde madde birikimi, BH: binuklear hücre, YHÇ: yassılaşmış hücre çekirdeği, BiD: belirgin olmayan iletim doku. (-): hasar yok, (+): az hasar, (++): orta hasar, (+++): şiddetli hasar.

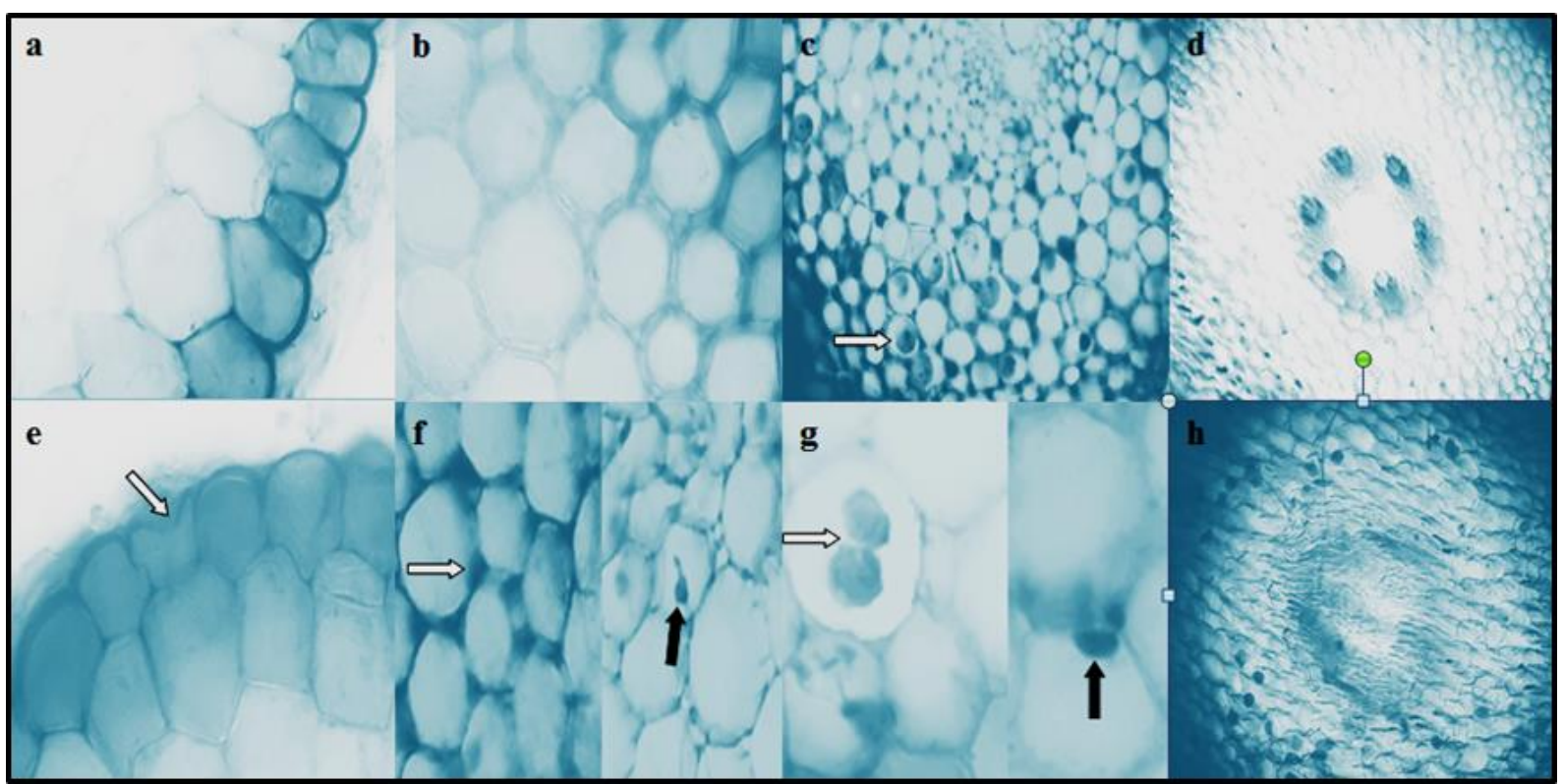

Şekil 2. Diazinon uygulamasının sebep olduğu meristematik hücre hasarı

[a: epidermis hücrelerinin normal görünümü, b: korteks hücrelerinin normal görünümü, c: hücre nükleusunun normal görünümü (oval), d: iletim dokunun normal görünümü, e: epidermis hücre hasarı, f: korteks hücre çeperinde kalınlaşma (beyaz ok) ve korteks hücrelerinde bazı maddelerin birikimi (siyah ok), g: binüklear hücre (beyaz ok) ve yassılaşmış hücre çekirdeği (siyah ok), h: iletim dokunun belirgin olmayan görünümü]. 
zencefil uygulanan Grup VI'daki korteks hücrelerinde madde birikimi ve binüklear hücre, kontrol grubunda olduğu gibi, tamamen kaybolmuştur. Bu hasarlardan binüklear hücre ve yassılaşmış hücre çekirdeği aynı zamanda diazinondan kaynaklanan genetik hasarın habercileridir. Öte yandan; korteks hücrelerindeki kalınlaşma bitkinin aşırı diazinon alımına karşı bir adaptasyonunu düşündürmüştür (Macar ve ark., 2020). İletim dokunun belirgin olmayan görünümü ve epidermis hücre hasarı diazinonun kök dokusunda enine taşınıdığını ve en dıştan en içe kadar her dokuda görülebilen etkileri tetiklediğini açık şekilde göstermektedir. Bu hasarlar MDA sonuçlarımız ile doğrulanan hücresel membran hasarlarının görünen sonuçları olarak da yorumlanabilir. Diazinon ya da zencefil uygulamalarının meristematik hücrelerdeki etkilerini gösteren başka bir çalışmaya rastlanılmamıştır.

\section{SONUÇ}

$\mathrm{Bu}$ çalışmanın sonuçları; diazinon ve zencefilin $A$. cepa kök ucu hücrelerindeki toksik etkilerini kapsamlı bir şekilde göstermektedir. Tehlikeli bir kirletici olan diazinon maruziyetinin, hedef olmayan canlılardaki olumsuz etkileri bilindiği halde; zencefilin bu risklere karşı koruyucu ve iyileştirici etkileri in vivo ortamda ve çok yönlü bir çalışma ile ilk kez gösterilmiştir. Artan dozlardaki zencefil uygulaması; diazinonun genotoksik ve sitotoksik etkilerini incelenen tüm parametrelerde hafifletmiş ve bu iyileştirici etki uygulanan zencefil dozuna bağlı olarak artış sergilemiştir. Biyokimyasal parametrelerden elde edilen sonuçlar; zencefilin koruyucu etkisinin, zencefilin olağanüstü antioksidan kapasitesi ile doğrudan ilişkili olduğunu göstermiştir. Tek başına uygulanan zencefil dozlarının incelenen parametreler bakımından kontrol grubuna göre hiçbir olumsuz etkiye yol açmaması, zencefilin yan etkisi olmayan, koruyucu bir fonksiyonel gıda olarak kullanılması konusundaki potansiyelini ortaya koymaktadır.

\section{KAYNAKLAR}

Abdel-Daim MM, Abushouk Al, Alkhalf MI, Toraih EA, Fawzy MS, ljaz H, Aleya L, Bungau SG (2018) Antagonistic Effects of Spirulina platensis on Diazinon-Induced Hemato-biochemical Alterations and Oxidative Stress in Rats. Environmental Science and Pollution Research 25(27): 27463-27470.

Abdelkhalek NK, Eissa IA, Ahmed E, Kilany OE, El-Adl M, Dawood MA, Hassan AM, Abdel-Daim MM (2017) Protective Role of Dietary Spirulina platensis against Diazinon-Induced Oxidative Damage in Nile tilapia; Oreochromis niloticus. Environmental Toxicology and Pharmacology 54: 99-104.

Al Hroob AM, Abukhalil MH, Alghonmeen RD, Mahmoud AM (2018) Ginger Alleviates Hyperglycemia-Induced Oxidative Stress, Inflammation and Apoptosis and Protects Rats against Diabetic Nephropathy. Biomedicine and Pharmacotherapy 106: 381-389.

Almostady AA, Mutwakil MH, ElAssouli MZ, Ahmed MM, El Assouli SM (2015) Genotoxicity and Antigenotoxicity
ÇAVUŞOĞLU K, MACAR O, KALEFETOĞLU MACAR T, YALÇIN E Activites of Rhazya stricta and Zingiber officinale Single and in Combination. American-Eurasian Journal of Agricultural and Environmental Science 15: 13921401.

Atik M, Karagüzel O, Ersoy S (2007) Sıcaklığın Dalbergia sissoo tohumlarının Çimlenme Özelliklerine Etkisi. Mediterranean Agricultural Sciences 20(2): 203-210.

Beauchamp C, Fridovich I (1971) Superoxide Dismutase: Improved Assays and an Assay Applicable to Acrylamide Gels. Analytical Biochemistry 44: 276-287.

Beers RF, Sizer IW (1952) Colorimetric Method for Estimation of Catalase. Journal of Biological Chemistry 195: 133-139.

Bıçakçı U, Çavuşoğlu K, Yapar K, Acar A, Yalçın E (2017) Allium cepa L. Kök Ucu Hücrelerinde Diazinon Toksisitesinin Araştırılması. Iğdır Üniversitesi Fen Bilimleri Enstitüsü Dergisi 7(3): 49-56.

Davies DB, Holub BJ (1980) Toxicological Evaluation of Dietary Diazinon in The Rat. Archives of Environmental Contamination and Toxicology 9: 637650.

Dehghani $\mathrm{MH}$, Kamalian $\mathrm{S}$, Shayeghi $\mathrm{M}$, Yousefi $M$, Heidarinejad Z, Agarwal S, Gupta VK (2019) Highperformance Removal of Diazinon Pesticide from Water Using Multi-walled Carbon Nanotubes. Microchemical Journal 145:486-491.

El-Shenawy NS, El-Salmy F, Al-Eisa RA, El-Ahmary B (2010) Amelioratory Effect of Vitamin $E$ on Organophosphorus Insecticide Diazinon-Induced Oxidative Stress in Mice Liver. Pesticide Biochemistry and Physiology 96(2): 101-107.

Fenech M (1993) The Cytokinesis-Block Micronucleus Technique: A Detailed Description of the Method and Its Application to Genotoxicity Studies in Human Populations. Mutation Research 285: 35-44.

Fenech M, Chang WP, Kirsch-Volders M, Holland N, Bonassi S, Zeiger E (2003) HUMN Project: Detailed Description of the Scoring Criteria for the Cytokinesis-Block Micronucleus Assay Using Isolated Human Lymphocyte Cultures. Mutation Research - Genetic Toxicology and Environmental Mutagenesis 534: 6575.

Fioresi VS, de Cássia Ribeiro Vieira B, de Campos JMS, da Silva Souza T (2020) Cytogenotoxic Activity of The Testicides Imidacloprid and Iprodione on Allium cepa Root Meristem. Environmental Science and Pollution Research 1-11.

Galloway T, Handy R (2003) Immunotoxicity of organophosphorous pesticides. Ecotoxicology 12: 345-363

Hajirezaee S, Mirvaghefi AR, Farahmand H, Agh N (2016) Effects of Diazinon on Adaptation to Sea-water by The Endangered Persian Sturgeon, Acipenser persicus, Fingerlings. Ecotoxicology and Environmental Safety 133: 413-423.

Han YA, Song CW, Koh WS, Yon GH, Kim YS, Ryu SY, Kwon $\mathrm{HJ}$, Lee KH (2013) Anti-inflammatory Effects of The Zingiber officinale Roscoe Constituent 12Dehydrogingerdione in Lipopolysaccharide-stimulated 
Raw 264.7 Cells. Phytotherapy Research 27(8): 12001205.

Hao M, Liu R (2019) Molecular Mechanism of CAT and SOD Activity Change under MPA-CdTe Quantum Dots Induced Oxidative Stress in the Mouse Primary Hepatocytes. Spectrochimica Acta Part A: Molecular and Biomolecular Spectroscopy 220: 117104: 1-11

Kalefetoğlu Macar T, Macar O, Yalçın E, Çavuşoğlu K (2020) Resveratrol Ameliorates the Physiological, Biochemical, Cytogenetic, and Anatomical Toxicities Induced by Copper (II) Chloride Exposure in Allium cepa L. Environmental Science and Pollution Research 27(1): 657-667.

Karamian A, Shokrzadeh M, Ahmadi A (2016) The Potential Chemoprotective Effects of Melatonin against Genotoxicity Induced by Diazinon in Human Peripheral Blood Lymphocytes. Toxicology and Industrial Health 32(2): 360-366.

Khanna N, Sharma S, (2013) Allium cepa Root Chromosomal Aberration Assay: A Review. Indian Journal of Pharmaceutical and Biological Research, 1(03): 105-119.

Macar O, Macar TK, Çavuşoğlu K, Yalçın E (2020) Determination of Protective Effect of Carob (Ceratonia siliqua L.) Extract against Cobalt (II) Nitrate-Induced Toxicity. Environmental Science and Pollution Research 27: 40253-40261.

Mao QQ, Xu XY, Cao SY, Gan RY, Corke H, Li HB (2019) Bioactive Compounds and Bioactivities of Ginger (Zingiber officinale Roscoe). Foods 8(6): 185.

Pandir D (2018) Assesment of the Genotoxic Effect of the Diazinon on Root Cells of Allium cepa (L.). Brazilian Archives of Biology and Technology 61: e18160390.

Saeidi M, Naeimi A, Komeili M (2016) Magnetite Nanoparticles Coated with Methoxypolyethylene Glycol as an Efficient Adsorbent of Diazinon Pesticide from Water. Advances in Environmental Technology 2(1): 25-31.

Sh G, Shabestani Monfared A, Zabihi E, Khoshbin Khoshnazar A, Asadi J, Abedian Z, Borzoueisileh S (2020) Changes in the Radiation Toxicity of Human Lymphoblastic T-cell Line (Jurkat) by a Common Pesticide: Diazinon. Journal of Biomedical Physics and Engineering 10(2): 147-154.

Shah MD, lqbal M (2010) Diazinon-induced Oxidative Stress and Renal Dysfunction in Rats. Food and Chemical Toxicology 48(12): 3345-3353.
Staykova TA, Ivanova EN, Velcheva IG (2005) Cytogenetic Effect of Heavy Metal and Cyanide in Contamined Waters from the Region of Southwest Bulgaria. Journal of Cell and Molecular Biology 4(1): 41-46.

Stoner GD (2013) Ginger: is It Ready for Prime Time?. Cancer Prevention Research 6(4): 257-262.

Tabasideh S, Maleki A, Shahmoradi B, Ghahremani E, McKay G (2017) Sonophotocatalytic Degradation of Diazinon in Aqueous Solution Using Iron-doped $\mathrm{TiO}_{2}$ Nanoparticles. Separation and Purification Technology 189: 186-192.

Trimedona N, Rahzarni R, Syahrul S, Muchrida Y, Roza I (2020) Antioxidant Properties of Herbal Tea Prepared from Red Dragon Fruit Peel with The Addition of Ginger. Journal of Applied Agricultural Science and Technology 4(2): 181-188.

Unyayar S, Celik A, Cekic FO, Gozel A (2006) CadmiumInduced Genotoxicity, Cytotoxicity, and Lipid Peroxidation in Allium sativum and Vicia faba. Mutagenesis 21:77-81.

USEPA (US Environmental Protection Agency) (1996) Seed Germination/Root Elongation Toxicity Test, OPPTS 850.4200, EPA712/C-96/154. In: Ecological Effects Test Guidelines. Washington, DC.

WHO (World Health Organization) (1985) Guide to shortterm tests for detectingmutagenic and carcinogenic chemicals. Environ. Health Criteria 51,Geneva, pp. 208

Zargar A, Taheri Mirghaed A, Mirzargar SS, Ghelichpour M, Yousefi M, Hoseini SM (2020) Dietary Ginger Administration Attenuates Oxidative Stress and Immunosuppression Caused by Oxytetracycline in Rainbow Trout (Oncorhynchus mykiss). Aquaculture Research 51(10): 4215-4224.

Zou J, Yue J, Jiang W, Liu D (2012) Effects of Cadmium Stress on Root Tip Cells and Some Physiological Indexes in Allium cepa var. agrogarum L. Acta Biologica Cracoviensia Series Botanica 54: 129-141.

Zulaikhah ST (2018) Effects of Tender Coconut Water on Antioxidant Enzymatic Superoxida Dismutase (SOD), Catalase (CAT), Glutathione Peroxidase (GPx) and Lipid Peroxidation in Mercury Exposure Workers. International Journal of Science and Research 4(12): 517-524. 